\title{
A racionalidade escolar como processo civilizador: a moral que captura almas
}

\author{
Carlota Boto \\ Universidade de São Paulo, Brasil
}

\begin{abstract}
Resumo
O objetivo deste artigo é o de enfocar o tema da civilização e das práticas de ensino da moral e da civilidade na escola. Tomando por referência teórica principal a obra de Norbert Elias, foram estudados livros didáticos portugueses utilizados em escolas entre meados do século XIX e os primeiros anos do século XX. Trata-se de uma pesquisa no campo da História da Educação, na qual os textos escolares são tomados como fontes. Verifica-se, por meio dos livros, o intuito da escola de ensinar um roteiro de comportamentos tidos como universalmente válidos. Há, por sua vez, nos compêndios, diferentes concepções de moralidade e diversas maneiras de se conceber o ensino da moral. Nota-se a existência de estratégias claras para acoplar, ao ensino do ler, do escrever e do contar, o ensino das formas de se comportar. Os saberes da escola primária constituem claramente uma forma de civilizar. O conceito de civilização traz implícita a suposição de superioridade de uma cultura sobre as outras. Os conhecimentos escolares aliam-se ao ensino de certas competências, de um dado repertório, que coincide com a orientação de valores e de saberes a serem percorridos; para que fossem formadas, inclusive, idéias de pátria, de família, de criança, de disciplina, etc.. A escola fala do mundo às crianças; de um mundo para o qual são necessários alguns sutis ensinamentos: 0 aprendizado do silêncio, da modéstia, da aceitação do existente como necessário, da obediência como valor na vida cotidiana.
\end{abstract}

Palavras-chave

História da Educação; Civilização; Escola; Compêndios didáticos

As recompensas, as punições, os prêmios, as palavras de elogio ou de censura insuflam na criança a convicção de que existe um bem e um mal, fins em si, como existe um sol e uma lua. Neste universo de coisas definidas e plenas, acredita ser, ela também, de maneira definida e plena: é um bom garotinho ou 
um mau sujeito; a criança conforma-se com isso. (...) Enquanto espera, brinca de ser: ser santo, herói, renegado. Sente-se semelhante a esses modelos dos quais seus livros desenham para ela imagens sem equívoco (Simone de Beauvoir, Moral da ambigüidade, p.30).

Este trabalho tem por propósito assinalar historicamente a perspectiva civilizadora da vida escolar, mediante recurso a conteúdos didáticos. Buscarse-á identificar representações escolares acerca da idéia de civilização e do papel conferido à escola como instituição civilizadora. As fontes estudadas são livros didáticos de alfabetização e de primeira leitura indicados para o ensino primário e utilizados em escolas primárias portuguesas entre a metade do século XIX e os primeiros decênios do século XX. A referência teórica do trabalho será o pensamento de Norbert Elias acerca do percurso civilizador, cuja interpretação permite abordar o campo da escola. A presente pesquisa debruça-se, pois, sobre saberes e valores transmitidos pela escola com o fito de formar condutas, modelar comportamentos; enfim, capturar almas. O ensino da moralidade, por parte da escola primária, confunde-se com o próprio percurso do letramento da criança.

Institucionalmente, a acepção de escola tem como características a racionalidade, a organização, a codificação de saberes e de valores, o sistemático recurso à abstração, que muito a aproximam das imagens da cultura letrada. De fato, a categoria "civilização escolar" parece-me operatória para reconstituir alguns aspectos internos à vida nas escolas. Nesse sentido, tal conceito (civilização) considera não apenas o caráter inventivo da cultura escolar e das práticas que originalmente são produzidas no cotidiano da instituição, mas supõe também o caráter de projeto social pressuposto na tarefa de escolarizar. Civilizar é indicar um caminho dirigido a um telos; e a escola é uma forma específica de civilizar. Cunhado no século XVIII, o próprio termo civilização carrega em si uma dupla pretensão: por um lado, trata-se de uma proposta universal. Todos participam da civilização; embora nem todos o façam no mesmo ritmo. Além disso, há uma idéia de progressivo aperfeiçoamento, de modo que a civilização não é apenas um estado, mas é também um movimento.

A cultura da instrução, que se institui para a infância pela escola, virá ancorada a um intento de representação do mundo, que buscará construir imagens acerca da realidade, consideradas apropriadas para as crianças. A 
escola pretende, com isso, direcionar o olhar e construir visões de mundo compatíveis com o mundo que a abriga. Trata-se, então, de produzir o efeito primeiro do acatamento das normas sociais vigentes. Nesse sentido, pode-se dizer com Marie-Madeleine Compère que "o tempo escolar é constitutivo da identidade moderna da infância" (1997: 11). O tempo vivido na escola adquire, no espaço de uma vida, papel civilizador. Segundo Marie-Madeleine Compère:

O tempo escolar pode ser, de fato, considerado como um dos lugares reveladores de toda uma civilização; posto que nele se reencontram, no plano das representações, bem como nas realidades um feixe de ideais e de interesses potencialmente em conflito: bem-estar das crianças e dos adultos, necessidades do Estado e da sociedade, e mesmo antes de o Estado nele se imiscuir, projeção de uma sociedade sobre seu futuro (1997: 9).

A escola alicerça-se na vida social como um passaporte para o mundo dos adultos. Estratégias escolares de instrução, formação e civilização instituem maneiras de preparar a infância e a adolescência para habilidades e saberes que Ihes serão, por suposto, requeridos na vida adulta. A família estrutura-se mediante laços de afeição. E, como já assinalava Alain (1986), o afeto não é paciente. A vida escolar exige, então, como contraponto daquela lógica familiar, a racionalidade de um profissional formado: o sujeito que tem na atividade de ensino sua profissão. Por causa disso, acredita-se que os professores são, relativamente aos familiares, mais aptos para instruir de maneira serena, sem deixar que as paixões os acometam. Têm técnica; e um 'saber-fazer'.

Os professores, assim como a escola, deverão trabalhar com a formação de saberes e de valores, necessariamente. Primeiramente, o ensino primário supõe, como é óbvio, o aprendizado de conteúdos concernentes à cultura letrada; mas a escolarização propicia também o exercício de nossas relações com os outros. A criança que chega à escola encontra nela, pela primeira vez, sua própria identidade; com nome e sobrenome. Ali ela representa, sim, sua linhagem familiar; e paradoxalmente está, até certo ponto, liberada dela. Isso é pedagógico. A rotina da escola possibilita o convívio entre os iguais. Há cumplicidade entre crianças da mesma idade; há também rivalidades, desavenças, afeições e desafetos. Tudo isso também é educativo: um contínuo aprendizado de equações dos conflitos inerentes à sociabilidade humana. 
A escola lida com normas impessoais. Regras públicas que orientam a vida da sala de aula estabelecem pactos de convivência dos alunos entre si, e deles com professores. A criança, no âmbito dessa vida entre regras, aprenderá a lidar com normas e com rituais que serão distintivos. Ela obterá hábitos de obediência; sim. Mas criará também hábitos de convivência, concentração, atenção, perseverança, disciplina, controle de si. No limite a escola institui, por seus ritos, por suas palavras e por seus sinais, uma cultura que lhe é própria; e que terá certamente um caráter civilizador. Pode-se dizer que a cultura escolar dialoga claramente com a codificação dos saberes da escritura: "saberes objetivados, delimitados, codificados, concernentes tanto àquilo que é ensinado quanto à maneira de ensinar" (Vincent, 1994: 30).

Os saberes da escola primária possuem claramente intenção de civilizar. O conceito de civilização traz implícito o suposto de superioridade de uma cultura sobre as outras: "quando se quer valorizar uma cultura em detrimento de outra, ou de todas as outras, fala-se em civilização (...) é a cultura apenas no que esta supostamente tem de mais elevado, ou é a cultura supostamente mais elevada" (Wolff, 2004: 25). Os livros de leitura destinados ao ensino primário claramente perfazem, em seu interior, estratégias de controle, instauração, preservação e perpetuação de valores, de tradições, de costumes existentes ou pretendidos por grupos em posição de poder na sociedade. Fazem isso, porém, apresentando as normas e preceitos dos saberes escolares como se estes fossem consensuais ou universalmente reconhecidos. Valeriam em tese para qualquer tempo, em qualquer parte. Nesse sentido, espera-se da escola que, ao ensinar, ela contribua para dirigir e regrar outras formas de aprendizado: para os séculos anteriores, especialmente a leitura espontânea; para os séculos XX e XXI os conteúdos dos rádios, da televisão, das histórias em quadrinho, do cinema, da internet, etc.

Os conteúdos escolares são apresentados como se significassem um corpo inamovível de conhecimentos, que coincidiria exatamente com o acervo cultural historicamente acumulado pela humanidade. A escola produz uma dada cultura, que por sua vez, valeu-se de estratégias de apropriação de outros significados culturais. O modo pelo qual a escola cria e recria seus significados culturais carrega as marcas de tal projeto civilizador. Como bem assinala Dominique Julia sobre esse tema, a própria constituição da idéia 
moderna de escola passava por essa captura de almas: "a cultura escolar desemboca aqui no remodelamento dos comportamentos, na profunda formação do caráter e das almas que passa por uma disciplina do corpo e por uma direção das consciências" (Julia, 2001: 22). Além disso, os rituais escolares não deixam de ter a feição de um "ver fazer e ouvir dizer" (Chartier, 2005: 14). Nesse sentido, de maneira astuciosa, os conteúdos do ensino são apresentados aos estudantes como se constituíssem a essência de uma tradição a ser perfilhada; a partir da qual, por meio do aprendizado, se estruturaria uma segunda natureza do sujeito. A escolarização assume, por essa lógica, a explícita finalidade de civilizar.

Acontece que civilizar significa, ao mesmo tempo, três coisas, como bem observa Francis Wolff:

(...) no primeiro sentido, civilização é civilidade; no segundo, é a parte espiritual da cultura; no terceiro, é a humanidade do sentido moral. O primeiro tipo de bárbaro parece pertencer a um estágio arcaico de socialização; o segundo, a um estágio arcaico da cultura; e, mais grave ainda, é a um estágio pré-humano que o terceiro parece pertencer: é o homem que permaneceu em estado selvagem, que se tornou, ou tornou a ser, desumano (2004: 23-4).

Gabriel Cohn (2004) indica a interface entre os conceitos de cultura e de civilização, dizendo o seguinte:

Civilização e cultura são dimensões inseparáveis do processo histórico, como figuras do universal e do particular. Trata-se de encontrar os elos entre ambas, não de identificá-las ou contrapô-las. Na dimensão da civilização o elo é dado pela civilidade; na dimensão da cultura, pela formação. Em ambos os casos, trata-se de imprimir forma à experiência: forma social num caso, forma significativa, no outro. A civilidade, como exercício, e a formação, como aprendizado, constituem, na sua unidade, o oposto da barbárie. Ambas remetem ao tema central da responsabilidade, que assume, no plano da civilidade, a forma do cuidado com o outro (p. 84).

Por causa disso, Cohn sugere que recolocar o vínculo entre civilização e cultura poderá ter operativamente efeito agregador:

Trata-se de recuperar o complexo significativo que anima a idéia de civilização e a torna inseparável da idéia de cultura, entendida esta na sua acepção mais plena, como cultivo da humanidade, como formação. Vida civil, livre convivência na cidade, cidadania e, indo mais fundo na etimologia, lar, abrigo, local de repouso em paz - tudo isso faz parte desse grande complexo, assinalando o grande tema de uma sociabilidade que permite a todos estarem chez soi (p. 82). 
A tarefa civilizadora da escola seria, sob qualquer aspecto, preventiva contra a barbárie. A acepção de barbárie, por sua vez, remonta a uma concreta possibilidade, sempre à espreita no mundo das culturas: "a barbárie existe em toda parte em que há uma regressão à violência física primitiva, sem que haja uma vinculação transparente com objetivos racionais na sociedade, onde exista, portanto, a identificação com a erupção da violência física" (Adorno, 1995: 159). A escola é a instituição que se dá a ver como lugar primeiro do cultivo da racionalidade: seja uma racionalidade no campo dos saberes, seja uma dada acepção sistemática de compreensão do domínio da ética. Para tanto, a escola expõe seus conteúdos como se eles fossem unívocos, pois é marca da civilização a aparência de uniformidade. Sucede que a escola auto-compreendida como civilizadora nomeia claramente os supostos bárbaros que não a acompanham. Por não falar ou compreender nossa língua, o bárbaro causa estranheza e suspeição; devendo, por tais razões, "ser mantido longe ou submetido" (Cohn, 2004: 84). O trabalho com a civilidade é, nesse sentido, um artefato da civilização. Apreender com alguma objetividade o conceito de civilização não é, todavia, tarefa fácil. Como alerta Francis Wolff (2004), há armadilhas na idéia:

(...) diz-se 'civilização ocidental' para designar um conjunto tão vasto quanto indeterminado no espaço e no tempo. Em última instância, uma civilização é algo tão amplo que nos referimos a ela no singular, a civilização, como se houvesse só uma. O bárbaro é, então, evidentemente, simplesmente, aquele que está sem civilização ou fora da civilização (p. 24).

A escola vale-se dessa estratégia de uma maneira bastante específica, apresentando o conhecimento como se ela partilhasse de sua autoria; como se os conteúdos pedagógicos houvessem sido inventados e cristalizados ali mesmo, na vida escolar. Daí a importância dos compêndios na forma escolar de se civilizar. Eles traçam, pela escola, um mapa orientador, uma diretriz cultural, um veículo de apresentação do que no mundo haverá de importante.

Pelo livro, o professor estuda. Por meio dele, uma dada representação do real será relatada às crianças. A escolarização, tal como ela se configura nas sociedades ocidentais, é expressão da modernidade. Ela integra o seu tempo e é constituída por ele: "se a escola é um dos tempos sociais de invenção e produção dos sujeitos, os sujeitos inventam e reinventam os tempos escolares. Tempos em que também se reinventam" (Faria Filho, 2001: 
134). Sendo assim, como assinala Luciano Mendes Faria Filho, a mesma escola que é constituída pela cidade, constitui a vida citadina; a mesma escola que é forjada pelo Estado-Nação, constrói também os alicerces do próprio Estado nacional. Nas palavras do autor:

Assim, é preciso perguntar também: como a escola organiza a experiência urbana? Aqui, poderíamos vislumbrar não apenas aquelas clássicas idéias de que a escola oferece (ou não oferece) aos sujeitos os elementos necessários à sua inserção na vida urbana, como o acesso à cultura escrita, mas também como a vida da cidade é organizada pela escola (Faria Filho, 2005: 36)

Estudos que hoje se têm debruçado sobre o percurso da escola moderna em diferentes países indicam continuidades e rupturas; por vezes, similitudes, por vezes, descontinuidades daquilo que Guy Vincent (1994) caracterizou como "forma escolar de socialização". Embora possamos verificar na cultura que a escola produz a inscrição da originalidade no tocante a demarcações de espaços e temporalidades que permeiam as relações de aprendizado, é possível constatar permanências nos protocolos e ritos postos em prática na vida cotidiana das escolas. Há neles o intuito de, por saberes e valores, codificar normas de convivência, organizar e classificar a hierarquia das funções sociais, pautar para os indivíduos projetos condignos de futuro e tecer uma sociabilidade condizente com a desejada ordenação do 'cosmos' social. A mesma escola que cria o efeito da disciplina e produz obediência é aquela que se propõe a racionalizar e civilizar.

A disciplina escolar abarca um minucioso conjunto de normas, de táticas, de procedimentos, cuja finalidade será tornar uno aquilo que, em princípio, era múltiplo. A ação reguladora das instituições educativas é constitutiva de nosso imaginário pedagógico contemporâneo. O poder disciplinar - como dirá Foucault - pretende engendrar corpos dóceis: "corpo que se manipula, se modela, se treina, que obedece, responde, se torna hábil ou cujas forças se multiplicam" (Foucault, 1987: 117). O registro disciplinar tem a ver com a idéia de adestramento. Por isso ele assusta a juventude. A docilidade a ser fabricada pelo efeito da obediência corresponde à idéia de manipulação de gestos, de símbolos, de palavras e de movimentos. Ao mesmo tempo, a ação autoritária produz sujeição e atividade. O poder cria aptidões e, ao mesmo tempo, submete energias. Por isso constrói "marcas rituais de obediência" (idem, p. 119). Trata-se, portanto, de uma astúcia da 
sujeição sempre controlada. Em alguma medida, a tarefa da escolarização passa por isso. Os alunos serão controlados por uma "anatomia política do detalhe" (idem, p. 121). A própria escola parece cercada. É um local separado dos outros, que impõe minuciosas distribuições: "cada indivíduo em seu lugar; e em cada lugar, um indivíduo. Evitar as distribuições por grupos; decompor as implantações coletivas, analisar as pluralidades confusas, maciças ou fugidias" (idem, p. 123). A disciplina classifica, ordena, mensura, avalia. Tratase de uma "arte de dispor em fila, e de técnica para a transformação dos arranjos" (idem, p. 125). Essa é uma forma plausível de pensar a institucionalização social da escola.

Há, porém, outros aspectos que não se explicam apenas pela matriz da disciplina. A escola racionaliza. Ao mesmo tempo em que distribui as pessoas, faz também com que elas circulem, mediante uma encadeada estrutura ritual. Vale-se do pensamento conceitual; mas age também por ações cifradas pelo hábito e pela tradição. Ao engendrar sua própria racionalidade, a escola civiliza. Por ser então uma instituição charneira do que Norbert Elias (1994) nomeou de "processo civilizador", a mesma escola terá com a família relações ambíguas (Boto, 1997); de mútua dependência e de rivalidade. A escolarização expõe-se na vida social como instância formadora por excelência. Nela serão contadas às crianças as coisas fundamentais para se tornar adulto; vale dizer, as intersecções e intercâmbios entre natureza, cultura e civilização. A escola moderna é, portanto, tributária de um esforço civilizador da vida social (Souza, 1998). A modernidade que, do ponto de vista da ciência, tem por marca o desencantamento do mundo, sob a perspectiva da sociabilidade, será impositiva de códigos reguladores das relações de convívio. Por um lado essa modernidade emancipa; por outro lado, ela controla - como já destacou Franco Cambi (1999).

A civilidade estrutura-se como estratégia de formação; e, portanto, como fator de coesão e persuasão social. A civilidade - reportando-se, ainda que indiretamente às acepções de polidez, urbanidade e cortesia (e verifiquese que todas essas palavras têm um prefixo derivado de instâncias políticas do convívio coletivo: cives, polis, urbes e corte) - agrega valor a conhecimentos que ilustram parâmetros de conduta. Starobinski relata que, na maior parte das línguas européias, a palavra civilização teria sido cunhada no século XVIII - embora, no limite, ela represente um movimento que lhe é 
anterior. Parecia imprescindível, nos termos de Starobinski, aparar asperezas sociais. O processo civilizador, por definição, abranda costumes, com vistas a interagir com hábitos sociais existentes e recomendados ou prescritos e desejados. Evidentemente, tratava-se de um percurso inventado, que, no limite, evocava usos e costumes de determinadas camadas sociais em situação de poder. Talvez isso explique aquilo que o autor considera ser também a má consciência contemporânea acerca da idéia de civilização. Costumamos pensar hoje a civilização não mais a partir de sua potencialidade, mas de seus males: "a civilização é percebida no discurso contemporâneo, ora como fonte do mal, ora como a vítima de um mal" (Starobinski, 2001: 50). Seu caráter ameaçador tem a ver, entre outras coisas, com sua pretensão prescritiva; à guisa de critério de julgamento. Nesse sentido, continua Starobinski, "a civilização constitui uma norma políticomoral: ela é o critério que permite julgar e condenar a não-civilização, a barbárie" (idem, p. 51). De todo modo, polir corresponderia a civilizar maneiras e, ao mesmo tempo, estruturar linguagens:

Se há aqui um inventário das instâncias civilizadoras (o tempo, as letras, a corte, a arte, a conversação das damas), tem-se também (...) toda uma lista de candidatos à transformação polida: os bárbaros, os provincianos, os jovens, em suma, a natureza 'feroz' e 'grosseira' antes que a arte se tenha encarregado dela para aperfeiçoar, isto é, para alterá-la em um processo de suavização, de ornamento e de educação. A colocação em pé de igualdade de tudo o que é suscetível de ser polido (e policiado) não deixa de ter importância: bárbaros, selvagens, gente de província (a fortiriori: camponeses), jovens (a fortiriori: crianças) se apresentam como uns tantos paradigmas substituíveis. Em comparação com a perfeição do polido, o bárbaro é uma espécie de criança, a criança é uma espécie de bárbaro. Para quem acentua o perigo da barbárie, não será difícil discerni-lo no meio de nós, no povo das distantes províncias, nas crianças entregues a si mesmas, por toda parte onde o polimento educativo não pôde intervir; para quem confia nos poderes da educação, não será difícil, correlativamente, considerar os selvagens como crianças, que um benévolo e paciente polimento tornará semelhantes a nós (idem, p. 28).

Para Starobinski, o percurso civilizador corresponderia a um "processo complexo de refinamento dos costumes, de organização social, de equipamento técnico, de aumento de conhecimentos" (idem, p. 32). Contudo a categoria civilização surgirá ela própria carregada de uma aura sagrada, reconhecida tanto pelos que pretendem louvá-la quanto pelos que tencionam condená-la. O conceito é apresentado, então, como critério de julgamento, parâmetro de medida: "julgar-se-á em nome da civilização" (idem, p. 33). E, 
por isso mesmo, cria-se uma relação entre um nós-civilizado e um outrobárbaro, onde o primeiro declara e firma sua pretensa superioridade diante do interlocutor. Nas palavras do autor:

Tudo que não é a civilização, tudo que the resiste, tudo que a ameaça, fará figura de monstro ou de mal absoluto. $\mathrm{Na}$ excitação da eloqüência, torna-se permissível reclamar o sacrifício supremo em nome da civilização. O que significa dizer que o serviço ou a defesa da civilização poderão, eventualmente, legitimar o recurso à violência. $\mathrm{O}$ anticivilizado, o bárbaro devem ser postos fora de condição de prejudicar, se não podem ser educados ou convertidos (idem, p. 33).

É preciso, então, educar o bárbaro; ou seja: a um só tempo, polir suas maneiras, policiar seus maus hábitos e incluí-lo na esfera da política. $\mathrm{Na}$ modernidade, essa tarefa competiria historicamente à escola.

Polir é civilizar os indivíduos, suas maneiras, sua linguagem. Tanto o sentido próprio quanto o sentido figurado podem conduzir à idéia de ordem coletiva, de leis, de instituições que assegurem a brandura do comércio humano. A passagem é feita pelo verbo policiar, que diz respeito aos indivíduos reunidos, às nações. Pela atuação do antônimo comum (que é barbárie), a palavra polícia alinha-se do lado de civilidade, polidez, civilização (idem, p. 29).

Também Philippe Bénéton situa a gênese do termo civilização na pretensão de suavizar maneiras. Destaca que a diferença da palavra civilização em relação àquelas que Ihe antecederam - cortesia, urbanidade, civilidade, polidez - estaria exatamente na indicação do sentido não apenas de um estado, mas de um movimento. Esse dito estado civilizado era, por sua vez, compreendido como hierarquicamente superior a outros que com ele conviviam. Nesse sentido, o século XVIII confere estatuto de civilização a práticas de imperialismo do Ocidente.

A palavra civilização nasce, portanto, marcada pela clivagem da distinção entre eu e os outros, entre o civilizado e o selvagem, entre o prescrito e o proscrito. Trata-se de um tipo de linguagem eivada de juízos valorativos acerca das relações de domínio e de poder. Diz Bénéton que "o vocabulário reflete assim claramente a pretensão do Ocidente ao monopólio 'da civilização'. Evolucionismo, etnocentrismo e universalismo aliam-se perfeitamente e conduzem de maneira bastante natural ao imperialismo" (Bénéton, 1975: 49). Haveria mundialmente uma missão civilizadora que aliaria os povos entre si; ao mesmo tempo em que, entre os mesmos povos, 
teceria intercâmbios e redes de dependências mútuas. Nesse sentido, alguns países encarnariam o processo da civilização, liderariam outros povos, a serem por eles conduzidos para tal missão civilizadora. Todos os povos participariam dessa civilização, mas de maneira desigual. Dessa maneira, o percurso civilizador abarcaria todas as pessoas; embora não o fizesse no mesmo ritmo.

Poderíamos dizer que, no interior dos vários países, todas as pessoas também integrariam redes de mútuas dependências; em um percurso que, de maneira combinada e desigual, integraria as populações em degraus diversos do estágio civilizatório. Sobre o tema, Bénéton (1975) acrescenta que, sob tal perspectiva, "os outros devem tomar como exemplo o nós. Os modelos são encarnados: o mundo civilizado é ocidental, o homem cultivado é burguês" (pp. 68-9). A cultura do Ocidente seria apresentada como cultura geral; oferecendo modelos culturais (Carvalho, 2006) a serem apreciados e imitados. As elites civilizadas por seu comportamento se reconheceriam enquanto tal; e o mundo da burguesia conviveria, de maneira aparentemente paradoxal, com uma aristocracia dos gestos. O bom tom dos comportamentos imporá marcas de distinção: as classes sociais dominantes reproduzirão também ali suas preferências; escolhendo como pares aqueles que se comportam como seus iguais.

Jacques Revel identifica o século XVI como período de intensificação dos usos e práticas de civilidade. Tratava-se, segundo o autor, de um "intenso esforço de codificação e controle dos comportamentos" (Revel, 1991: 169). A vida em sociedade estabelecia exigências. A civilidade, nesse sentido, conformar-se-ia como uma moral reguladora do espaço público. Revel comenta que se tratava efetivamente de "uma linguagem dos corpos, sim; porém destina-se aos outros, que devem poder captá-la. Ela projeta o indivíduo para fora de si mesmo e o expõe ao elogio ou à sanção do grupo" (idem, p. 169). A aprendizagem da civilidade, entre outras coisas, requereria, então, a submissão dos corpos. Como observa Renato Janine Ribeiro, havia nesse universo algo para além do mero repertório de modos de agir: "é preciso que os gestos e as palavras considerados belos adquiram um sentido cerimonial, tomem a forma de um ritual quase religioso. É preciso que as boas maneiras, esta redução da ética a uma estética, do bom ao belo, se enraízem numa política" (Ribeiro, 1990: 23). A idéia de civilidade, por isso mesmo, seria, 
em alguma medida, oposta às dimensões da intimidade. Tratava-se de criar convenções para partilhar coletivamente significados que seriam públicos; postos em 'uso' pela cidade. O modo escolar de civilizar é também uma maneira de engendrar o ritmo da vida em cidades. Acerca do tema, Richard Sennett indica que o próprio termo civilidade, tendo o mesmo radical de cidade, indica um movimento tendente a denotar uma dada arte de representar para os outros:

Cidade e civilidade têm uma raiz etimológica comum. Civilidade é tratar os outros como se fossem estranhos que forjam um laço social sobre essa distância social. A cidade é o estabelecimento humano no qual os estranhos devem provavelmente se encontrar. A geografia pública de uma cidade é a institucionalização da civilidade (Sennett, 1988: 323-4).

Peter Burke, a propósito da tradição da história cultural, reconhece o livro de Norbert Elias datado de 1939 sob o título O processo civilizador como referência importante para historiadores culturais como Roger Chartier. Diz Burke também que "o uso crescente do termo 'civilidade' na obra de historiadores de fala inglesa é um indicador da importância cada vez maior de Elias, mesmo que o conhecimento de sua obra seja praticamente restrito" (Burke, 2005: 73). Em sua obra sobre a dinâmica do Ocidente, Norbert Elias destaca que o percurso civilizador abarcaria a um só tempo uma dimensão psicológica e um mecanismo de racionalização social. Por ser assim, civilização "não é fenômeno isolado; ela traduz uma mudança que afeta a economia psíquica em seu conjunto, o hábito de levar em consideração os prolongamentos de nossos atos, que a divisão progressiva das funções postula e cultiva" (Elias, 1975: 242). A premissa que dirige o conjunto da obra de Elias, como constatou Cynthia Greive Veiga, reside na tentativa de apreensão das relações de poder existentes em uma dada sociedade "a partir das relações de interdependência, uma vez que as coerções sociais são coerções que muitos homens, conforme sua dependência recíproca, exercem uns sobre os outros" (Veiga, 2005: 146). Controlar pulsões, racionalizar gestos e movimentos, disciplinar condutas, destacar voluntariamente os usos agenciados das potências do corpo, com o fito de estabelecer planos de longo prazo... A civilização conduziria, de acordo com Elias, a rotinas semiautomáticas. Deseja-se imprimir em cada um formas semi-conscientes de autocontrole, como dispositivos formadores de uma segunda natureza. Essa seria a lógica. As interdependências - enquanto cimento da sociedade - 
deveriam estruturar-se mediante esforços de regulação da vergonha. Não se tratava de um desenho voluntariamente traçado com intenção de domínio, mas também não era um caminho irracional. Havia nisso, não se pode deixar de reconhecer, um quê de arbitrário cultural.

Acerca do tema, Norbert Elias comenta:

Duas idéias se fundem no conceito de civilização. Por um lado, ela constitui um contraconceito geral a outro estágio da sociedade, a barbárie. Este sentimento há muito permeava a sociedade de corte. Encontrara sua expressão aristocrática de corte em termos como politesse e civilité. (...) A civilização não é apenas um estado, mas um processo que deve prosseguir. Este é o novo elemento manifesto no termo civilisation. Ele absorve muito do que sempre fez a corte acreditar ser - em comparação com os que vivem de maneira mais simples, mais incivilizada ou mais bárbara - um tipo mais elevado de sociedade: a idéia de um padrão de moral e costumes, isto é, tato social, consideração pelo próximo, e numerosos complexos semelhantes (Elias, 1994: $62)$.

A construção da escola moderna terá a marca de tal matriz civilizadora. A escola que ensina o ler, escrever e contar pretende, acima de tudo, civilizar - ou seja, conferir prioridade à transmissão sistemática e institucional de formas de se comportar. Tornar civilizada uma sociedade supõe ampliar sistematicamente o raio da racionalidade no trato. Abrandam-se as maneiras, criam-se sutilezas para o intercâmbio social, oferece-se um padrão de conduta de distinção, ao qual serão opostos como bárbaros todos os comportamentos divergentes. Norbert Elias observa que "os adultos suscitam assim, em parte de maneira automática, em parte conscientemente por sua conduta e por seus hábitos, as condutas e atitudes análogas nas crianças. A criança é condicionada desde sua primeira infância em direção a essa reserva e a esse hábito de previsão, que lhes serão necessários para que ela possa exercer, um dia, as funções de adulto" (Elias, 1975: 196). A contenção e a reserva seriam, para a criança, uma forma de auto-vigilância dos afetos, das emoções e das paixões.

Não podemos, todavia, nos esquecer do fato de o próprio Freud, quando escreveu, $O$ mal-estar na civilização, haver dito que a tarefa civilizatória era a de "proteger os homens contra a natureza" (Freud, 1997: 42). Ordenar a natureza e, nesse sentido, organizar seus significados seria, por sua vez, um dos propósitos da civilidade, que encaminha a sociedade para a existência dita civilizada. Freud destaca que os seres humanos teriam 
"uma tendência inata para o descuido, a irregularidade e a irresponsabilidade em seu trabalho" (idem, p. 47). Contra tal tendência, institui-se a exigência da ordem. Esta seria, a rigor, "uma espécie de compulsão a ser repetida, compulsão que, ao se estabelecer um regulamento de uma vez por todas, decide quando, onde e como uma coisa será efetuada, e isso de tal maneira que, em todas as circunstâncias semelhantes, a hesitação e a indecisão nos serão poupadas" (idem, p. 46). A civilização dirigir-se-ia, nesse sentido, tanto para a utilidade quanto para a satisfação das exigências da vida comum entre pessoas. Os relacionamentos sociais bem como a vida em comunidade requereriam a explicitação de parâmetros reguladores da conduta humana. $A$ civilização se institui quando a referência coletiva torna-se maior e mais forte do que as determinações dos desejos individuais: "a substituição do poder do indivíduo pelo poder de uma comunidade constitui o passo decisivo da civilização. Sua essência reside no fato de os membros da comunidade se restringirem em suas possibilidades de satisfação, ao passo que o indivíduo desconhece tais restrições" (idem, p. 49). Ser civilizado, nesse sentido, supõe a frustração do desejo, o recalque, a culpa e, ainda nos termos freudianos, a sublimação.

A sublimação do instinto constitui um aspecto particularmente evidente do desenvolvimento cultural; é ela que torna possível, às atividades psíquicas superiores, científicas, artísticas ou ideológicas, o desempenho de um papel tão importante na vida civilizada. Se nos rendêssemos a uma primeira impressão, diríamos que a sublimação constitui uma vicissitude que foi imposta aos instintos de forma total pela civilização. (...) É impossível desprezar até que ponto a civilização é construída sobre a renúncia do instinto, o quanto ela pressupõe exatamente a não-satisfação (pela opressão, repressão, ou algum outro meio?) de instintos poderosos. Essa frustração cultural domina o grande campo dos relacionamentos sociais entre os humanos. (...) Não é fácil entender como pode ser possível privar de satisfação um instinto. Isso não se faz impunemente (Freud, 1997: 52).

A socialização das novas gerações envolve na vida social parâmetros culturais que indicam a responsabilidade do adulto sobre aquele que, por sua ascendência, será formado. Como diz Hannah Arendt, diante do jovem, o educador age como um franco "representante de um mundo pelo qual deve assumir a responsabilidade, (...) ainda que secreta ou abertamente possa querer que ele fosse diferente do que é" (Arendt, 2000: 239). reconhecimento da assimetria intrínseca às clivagens geracionais favorece a relação pedagógica, bem como o empreendimento civilizador que lhe é 
constitutivo. Haveria, assim, alguma racionalidade no processo civilizador racionalidade esta que faz da escola sua instituição estratégica.

Marta Carvalho atenta para a função meta-normativa dos impressos escolares. Os discursos pedagógicos inscritos nos compêndios didáticos em uso nas escolas sinalizam normas e prescrições pedagógicas. Haveria, nesse sentido, um duplo movimento: "discursos pedagógicos como sistema de regras que, constituindo o campo, os objetos e os objetivos das práticas e dos saberes escolares, regulam também os processos materiais de produção, difusão e apropriação desses saberes" (Carvalho, 2006: 146). Trata-se, assim, de uma via de mão dupla. As representações criam práticas que, por sua vez, engendram novas representações.

\begin{abstract}
Levar em conta esse duplo papel normativo do discurso pedagógico é empreendimento que, de certo modo, reabilita a antiga história das idéias educacionais. Mas submete essas pedagogias a um questionário formulado no quadro das redefinições conceituais que vêm configurando a historiografia educacional contemporânea: a rehistoricização da escola; a atenção dada aos dispositivos constituintes de um modelo (Nóvoa...) ou de uma forma escolar (Vincent...) e às táticas de um saber fazer (Certeau...; Chartier...); o interesse pelos saberes pedagógicos como dispositivos de conformação de práticas escolares, mas também como matéria de apropriação, nos fazeres cotidianos da escola; a ênfase nas representações que agentes determinados fazem de si mesmos, de suas práticas, das práticas de outros agentes, de instituições como a escola - e dos processos que as constituem (Carvalho, 2006: 146).
\end{abstract}

A escola moderna firma-se progressivamente como instância civilizadora. Nos manuais de ensino primário, é bastante comum a idéia de moral transmitida pelo texto vir costumeiramente acoplada a um roteiro de comportamentos pré-ordenados, que estruturam uma relação estreita entre condutas prescritas de civilidade e concepções de bem. A moral escolar é pois bastante tributária da força do exemplo de narrativas criadas para efeito de cópias ou de ditados, que, ao mesmo tempo em que deviam ensinar a leitura, a escrita e a gramática, veiculariam formas de conduta valorizadas pela sociedade adulta para formar suas crianças. Perscrutar, portanto, o telos civilizador da escolarização primária supõe, de alguma maneira, percorrer esse repertório; e isso é o que nos propomos fazer aqui. Procuraremos, a seguir, identificar, em compêndios de ensino primário utilizados pela escola portuguesa entre o último quartel do século XIX e os primeiros anos do século $\mathrm{XX}$, algumas concepções de dever e de justiça ali perfilhadas. 
Manuel Justino Pires - professor particular de instrução primária da cidade de Elvas, na região do Alentejo, em Portugal -, no ano de 1851, justificava a apresentação de sua obra Rudimentos da leitura portuguesa com exercícios para soletrar em letra redonda, itálica, gothica e manuscripta offerecidos á sociedade elvense, recorrendo aos seus próprios atributos morais; considerados - sob sua perspectiva - como imprescindíveis para o exercício consciencioso do magistério. Ainda na capa, "quase a título de epígrafe", ele compendia sua máxima: "transmita o professor, a par das letras, as luzes da moral e da virtude" (Ministério do Reino, Mç. 3527). Além disso, recorria a sua opção de vida profissional para explicar as razões do livro que acabara de escrever. Diz então que se dedicava ao "triste e penoso exercício do Magistério" (Ministério do Reino, Mç. 3527) desde 1834, "sempre trabalhando para bem educar a puerícia, ensinando-lhe, a par dos conhecimentos literários, as máximas da Religião e Civilidade Christã para formar membros úteis à Pátria e à Sociedade" (idem, ib.). Nesse sentido, explicita que sua intenção com a referida obra não era a de "vil mercenário", mas de um "pai cuidadoso" (idem, ib.); como se a prática da paternidade fosse melhor reputada do que o ofício de professor. Sob tal estatuto de pai zeloso, ele teria "procurado, durante os dezesseis anos de minhas fadigas, o método mais fácil para transmitir aos meninos aquelas disciplinas que são próprias da sua inteligência e que fazem o objeto da instrução elementar" (idem, ib.). Com essa justificativa, ele submete seu "opúsculo" à apreciação do Conselho Superior de Instrução Pública, a quem caberia julgar o mérito pedagógico dos livros didáticos utilizados em Portugal daquele tempo. Aparece claramente na justificativa dada pelo professor para a aliança entre ensino dos saberes escolares e transmissão de normas morais e de códigos de comportamento. Esse tríplice vértice seria o alicerce sobre o qual repousaria a tarefa do magistério.

Códigos de moralidade não podem ser traduzidos em linguagem simples para o acesso das crianças. A primeira constatação facilmente obtida é a de que os preceitos éticos veiculados pela escola remetem preferencialmente para uma moral deontológica: fazer o bem como dever intransitivo. A escolarização toma como paradigma a perspectiva kantiana de ética, ancorada na idéia de autonomia da vontade moral. A moral é compreendida como um universo pautado por leis universalmente dadas à 
razão humana como imperativos categóricos. A obediência da vontade à lei moral independentemente de qualquer móbil para o agir, seria indicativa da autonomia da razão. A lei moral seria então, para o sujeito racional e autônomo, um mandamento incondicional: um imperativo universal do dever; e deste por sua vez decorreria necessariamente a ação prática. Por ser universal o imperativo categórico, a lei moral seria necessária:

(...) não contendo o imperativo, além da lei, senão a necessidade da máxima que manda conformar-se com esta lei, e não contendo a lei nenhuma condição que a limite, nada mais resta senão a universalidade de uma lei em geral à qual a máxima da ação deve ser conforme, conformidade essa que só o imperativo nos representa propriamente como necessária (Kant, 1988: 59).

Para Kant, a vontade é autônoma quando for capaz de determinar leis (universais) para si mesma: "a vontade é concebida como a faculdade de se determinar a si mesmo e agir em conformidade com a representação de certas leis. E uma tal faculdade só se pode encontrar em seres racionais" (Kant, 1988: 67).

Sucede que a criança não teria vontade autônoma; não é capaz de dar leis a si mesma. É então compreendida como um ser heterônomo; inábil para discernir entre o bem e o mal, não distinguindo, portanto, o certo e do errado. Paulatinamente havia de se formar o caráter moral da criança; e essa é uma das tarefas que a educação ( e especificamente a educação escolar) assume para si como função civilizatória. Ora, em um primeira etapa (exatamente aquela que compreende o ensino primário), como se supõe que as crianças não serão capazes de compreender os sentidos da moralidade, apresentamse a elas os valores como uma tábua de normas inquestionáveis a ser acatada. Não se fornecem as razões. Expõem-se diretrizes ${ }^{1}$.

Em geral, os significados das lições da escola primária apresentam-se como um roteiro no qual a justificação dos atos fica sob encargo exclusivo dos adultos. Esses, sob tal perspectiva, não se equivocarão jamais. Por isso, o dever principal da criança é a obediência. A história intitulada 'O Bem e O Mal, narrada em 1897 por José Quintino Travassos Lopes - inspetor de instrução primária das escolas portuguesas - em seu livro Leituras correntes e intuitivas (então indicado para uso das $2^{\underline{a}}$ s séries), é bastante ilustrativa desse modo de ver o assunto. Dois irmãos conversando, indagam-se sobre como fazer para diferenciar a boa da má ação. É porque a ação pode ser vista e conferida 
pelos adultos de suas relações primárias que o menino qualifica a ação de 'boa'. O adulto que tem ascendência sobre a criança é caracterizado como referência. Não há, assim, razão interna para a ação. Nesse caso, a moral é assinalada às crianças por sua exterioridade.

- Quando tu sabes as lições, ou quando brincas comigo tens receio de que te vejam?

- Não.

- É porque o que fazes é bem feito.

- Espera. Então, se faço uma ação que desejo ocultar à mamã, é porque essa ação é má; se desejo que ela a veja, é porque é boa?

- Sim, sim!

- Quem te ensinou isso?

- O papá.

- Vou ver se entendi o que o papá te ensinou. - Juliana, aqui tens este abraço. - Esta ação é boa, porque não tenho receio de que a mamã a veja?

— Sim, sim, meu bom Marcos (Lopes, 1897: 30)

Em outras passagens, o estudo da moral é recomendado às crianças como recurso para facultar a elas o reconhecimento da distinção entre o bem e o mal; já que uma ação só pode ser qualificada como eticamente condenável à luz do seu caráter voluntário. O mal praticado involuntariamente surge como um problema do ponto de vista do julgamento ético. Daí a necessidade da educação do juízo moral. Passa-se aqui a considerar o plano das intenções...

Conhecemos muitas vezes o bem, e, todavia, por fraqueza, praticamos o mal; assim como sucede faltarmos ao cumprimento do nosso dever em virtude de 0 ignorarmos. Tal é o caso da criança, que, sem escrúpulo, atormenta os animais, enquanto ignora que isso é um mal. Portanto, para o homem ser honesto, é necessário: $\left.1^{\circ}\right)$ conhecimento do dever; $2^{\circ}$ ) vontade e possibilidade de 0 cumprir. A moral propriamente dita estuda os costumes, tais quais eles deviam ser, e não como se encontram na sociedade" (Castanheira, 1903: 53).

A despeito de declarar que o estudo da moral não é comprometido com práticas e ações socialmente em voga, uma das principais estratégias de apresentação dos valores morais para as crianças é trazê-los acoplados a exemplos. Supondo ser heterônoma a ética da infância, dado que as crianças não são capazes de dar leis a si próprias e postular essas leis à luz de valores universais - critérios necessários para assegurar o juízo moral autônomo ${ }^{2}$-, sugere-se a elas que copiem os outros. Há aprendizado por imitação. E o 
aprendizado da moral ocorreria em grande parte por reprodução do exemplo. Como já destacava Marta Carvalho, um dos princípios que regulava os próprios livros destinados aos professores acerca da 'arte de ensinar' residia na repetição e imitação como fatores fecundos de aprendizado. Comenta a autora que, sob tal perspectiva, "o primeiro passo seria a imitação de atos alheios; o segundo, a reprodução voluntária desses atos; o terceiro, a reprodução de atos passados e, finalmente, o quarto, a imitação ou a realização daqueles que são imaginados" (Carvalho, 2001: 153). A palavra do professor sugere; e isso é suficiente para conduzir o discípulo a desejar, para ser como o professor, agir e fazer como ele. Só que nem tudo deve ser copiado. Era necessário ter cautela.

Quantas vezes o nosso professor nos tem dito que imitemos os bons exemplos?! Assim, se qualquer de nós sobressai aos outros, pela seriedade, pelo arranjo e pelo amor ao trabalho, será esse que deve servir de norma a todos os condiscípulos. Para que sejamos virtuosos, é preciso seguir os bons exemplos e isto não é muito difícil. Só de nós depende, com efeito, sermos respeitosos para com os nossos pais e para com os nossos professores; bons para com os nossos iguais. Para isto basta querermos. Aqui está por que o nosso professor tem razão, quando nos manda imitar os bons exemplos. Não imitemos, todavia, sem uma certa cautela. Assim, por exemplo, há pessoas de certa condição, que, por inveja ou vaidade, querem viver como os ricos. Isso muitas vezes custa caro. Quem gasta mais do que tem, para fingir de rico, torna-se desgraçado e quer assemelhar-se à rã, que, para imitar o boi, tanto inchou, que rebentou! Imitemos, pois, só os bons exemplos (Machado.b, s/d, p. 12).

Ulisses Machado - autor do excerto acima transcrito - é um daqueles autores de livros didáticos que migra com facilidade do período monárquico para a época republicana. As constantes reedições de seus livros revelavam adesão da escola a seus textos. O Livro de leitura para a segunda classe do ensino primário geral, em sua 15 edição, principiava com explicações sobre os conceitos de escola, de classe, de quadro preto, de ardósia e de caderno. Depois, discorria sobre as razões pelas quais a leitura é importante. Explicava também as razões de ser da escola; que, por um lado, ensina coisas úteis que se ignoram e, por outro lado, ensina também que se deve fazer o bem e fugir do $\mathrm{mal}^{3}$. O dever é algo que existe enquanto tal; uma coisa em si, universalmente dada e passível de ser universalmente reconhecida. Desse modo, torna-se postulado contido no livro e explicitado por uma lógica que é a do adulto; lógica essa que não compete à criança pretender compreender 
antes de 'chegar a hora'. Algumas coisas devem ser feitas; outras não podem ser feitas. Se eu devo, eu posso; e se eu não posso, eu não devo; já que o dever seria "mandamento incondicional [que] não deixa à vontade a liberdade de escolha relativamente ao contrário do que ordena, só ele tendo, portanto, em si aquela necessidade que exigimos na lei" (Kant, 1988: 57). O dever seria então derivado de uma lei prática; que os adultos conhecem. Simples como isso:

O não é uma palavra bem pequena, todavia nem sempre é fácil dizê-la. Muitas vezes nos arrependemos de não a ter dito. Quando nos convidam para alongar o nosso caminho, devemos dizer: não. Quando nos querem fazer conversar, rir ou brincar durante a aula, devemos dizer: não. Quando nos aconselham a desobedecer aos nossos pais ou aos nossos professores, ou a fazer qualquer outra coisa proibida, devemos dizer: não. Evitaremos assim muitas ações más e pouparemos a nós mesmos muitos desgostos (Machado, s/d, a): 23).

A acepção de moral perfazia em alguns livros a expressa intenção de formar hábitos de virtude. O significado da virtude é, por sua vez, costumeiramente apresentado sob perspectiva cristã: "uma disposição habitual da nossa alma, que nos dá o poder sobrenatural de praticar o bem e evitar o mal" (Anaquim, 1906: 26). A fé, a esperança e a caridade - virtudes teologais - seriam uma dádiva de Deus para iluminar a alma humana. As tais virtudes teologais aliar-se-iam as morais; e virtudes morais "são as que regulam os nossos costumes segundo os preceitos da vida cristã" (idem, p. 27): prudência; justiça; fortaleza e temperança. Todas elas indicariam o caminho do que o compêndio qualifica por aperfeiçoamento moral (idem, p. 45). Nesse sentido, a moral tem por âncora a religião e a ação. Pelas atitudes avalia-se o caráter moral; daí a proximidade do tema com o universo da civilidade. Praticar o bem é "fazer ações boas, pensar e falar segundo o ditame da própria consciência" (idem, p. 41). Dentre outras coisas, o ensino da moral é apresentado à luz de um conjunto de princípios como um guia de ação; cujos frutos podem ser apreciados pelas próprias crianças:

(...) fazendo-lhes sentir, na ocasião, as tristes conseqüências dos vícios, que, por vezes, se ostentam à sua vista, como a embriaguez, a preguiça, a insubordinação, a crueldade, etc; inspirando-lhes, todavia, tanta compaixão pelas vítimas do mal, como horror ao próprio mal; servindo-se de exemplos concretos, ou apelando para a experiência imediata para as habituar ao sentimento prático da moralidade (Anaquim, 1906: 40). 
É possível, porém, reconhecer na produção didática ora analisada critérios concorrentes acerca do valor moral. Primeiramente, como vimos, era usual apresentar a moral a partir da referência exclusiva de um dever assinalado à guisa do que Kant nomeou imperativo categórico. Este, em linhas gerais, é aquele que "não se relaciona com a matéria da ação e com o que dela deve resultar, mas com a forma e o princípio de que ela mesma deriva; e o essencialmente bom na ação reside na disposição, seja qual for o resultado. Este imperativo pode chamar-se o imperativo da moralidade" (Kant, 1988: 52).

Havia, contudo, outra representação acerca da formação do juízo moral: perspectiva fundada na determinação do bem a partir da expectativa das conseqüências dos atos.

Carlos José Barreiros, em seu livro Elementos de moral para uso das escolas, publicado em 1858 (com a folha de rosto indicando ser a obra "adequada à capacidade dos alunos de instrução primária"), observa que ações boas ou más são aquelas acompanhadas por efeitos bons ou maus. $\mathrm{O}$ texto é apresentado como um código de leis; e em seu Artigo $V$ da Parte $I$ dispõe sobre os conceitos de prêmio e de castigo. Há uma naturalização de tais idéias como respeitantes necessariamente à dimensão moral. Esta, por suposto, revelaria uma forma única e essencial para todos os lugares e todos os tempos. O texto de Barreiros discorre sobre um mundo dividido entre o bem e o mal - os adeptos do bem contra os praticantes do mal:

36. Prêmio é um bem anexo à ação boa, com o fim de nos incitar a continuarmos a praticar ações boas.

37. Pena ou castigo é um mal conexo à ação má, com o fim de nos incitar a não continuarmos a praticar tal ação. (E daqui se segue que os prêmios e penas aplicados aos outros homens também são de utilidade para nós).

38. Justiça, neste sentido, denomina-se a aplicação do prêmio à ação boa, e do castigo à ação má; e quem a aplica chama-se juiz.

39. O contrário chama-se injustiça. (Barreiros, 1858: 17-8)

Essa mesma ética conseqüencialista aparece frequentemente no uso de provérbios ou adágios populares, bem como na recorrência a máximas morais, cujo fito era o de estabelecer um elo de subordinação lógica entre o princípio e o resultado da ação. Aqui havia uma relação condicional: o bem era feito por visar algo que lhe seria exterior. Isso é o que faz, por exemplo, o livro 
O expositor portuguez ou rudimentos de ensino da língua materna, publicado em Lisboa ainda nos primeiros anos do século XIX. Na quarta edição, de 1846, lemos o que se segue: "o que não ouve conselhos raras vezes acerta; se quereis ser rico, poupai todos os anos alguma parte das vossas rendas; quem despende mais do que tem, por muito que tenha, sempre é pobre; a arma do sábio é a razão, a do ignorante a força" (Midosi, 1846: 125). Vê-se aqui a força moralizadora do provérbio que age como uma lição de vida; que elege rotas e ensina caminhos. Astucioso, o provérbio escorava-se na pedagogia do sentido comum; e ocultava-se no compêndio didático. Como bem recorda Natalie Davis - a propósito da cultura do povo do século XVI -, os provérbios sempre "inspiravam reflexões sobre a moral e podiam tornar alguém mais persuasivo, irônico ou severo (Davis, 1990: 201).

Os compêndios escolares eram fundamentalmente guias para o professor dirigir e dividir suas aulas. Mas explicitavam também protocolos sociais de ordenamento de parâmetros reguladores da inserção do aluno na vida social. Pelos livros, a escrita escolar estrutura-se como um "gesto estratégico" (Chartier, 2005: 22). Para os alunos, a moral e a civilidade transmitidas pelos livros tornar-se-iam, progressivamente - como o próprio livro - um uso, um costume: "o manuseio do texto escolar foi organizado como um ritual (Bittencourt, 1993: 282). O professor era o mediador de um conhecimento que o transcendia, inclusive no domínio da moralidade. De todo modo, os saberes escolares aliavam-se a uma dada cosmovisão, cujo repertório coincide com a orientação de valores a serem percorridos, para que fossem formadas idéias de pátria, de família, de criança, de disciplina, etc.. A escola fala do mundo às crianças; de um mundo para o qual são necessários alguns sutis ensinamentos: o aprendizado do silêncio, da modéstia, da aceitação do existente como necessário, da obediência como condição da vida cotidiana. Na maioria das vezes, os valores e o mérito eram medidos pela atitude que os acompanhava, mas nem sempre. O tema da moral pressupõe nele próprio alguma ambigüidade; e a intenção que preside o ato também é considerada como um valor. Ao se indagar, por exemplo, como proceder ao que qualifica por aperfeiçoamento moral, o Compendio de moral e doutrina christã escrito pelo Cônego Manuel Anaquim, publicado em Lisboa em 1906, destaca, dentre outras coisas, a sinceridade como atitude de vida: 
A pessoa que é digna, não tem que ter medo de manifestar o que é, nem de dizer o que pensa; a franqueza é qualidade das almas grandes; o hipócrita, afetando o que não é e fingindo virtudes e qualidades que não tem, a si mesmo se condena. E devemos igualmente ser sempre verdadeiros e sinceros, pois a mentira, além de ser um vício detestável, só serve ordinariamente para nos comprometer e envergonhar. É certo que nem todas as verdades se dizem; todavia, quando tivermos de nos manifestar, é sempre com verdade que o devemos fazer (Anaquim, 1906: 51).

Alguns outros livros serão historicamente mais receosos da sinceridade enquanto valor moral. Valoriza-se, sim, a expressão da verdade, desde que essa seja feita à luz da prudência. Para a criança, ser sincero seria então admitir as faltas; confessar-se, pedir perdão:

A sinceridade tem o coração nas mãos, mas, quando as abre, é com bom-senso e discrição. Há pessoas que, negando as faltas, julgam ganhar a estima dos outros. É um engano, porque ninguém mais acredita nessas pessoas. Não há nada como confessar a culpa. Lá diz o ditado: 'pecado confessado está meio perdoado (MORAL..., 1930: 35).

Ilustrativa do caráter civilizador intrínseco à escolarização moderna em seu modelo (Nóvoa, 1995, 2002), em sua forma (Vincent, 1994), em sua gramática (Tyack \& Cuban, 1995) - é a estrutura interna do Manual Encyclopedico. Esse livro - escrito para as escolas de instrução primária por Emílio Achilles Monteverde, em sua oitava edição, com data de 1865 apresenta o conjunto de saberes da escola portuguesa de primeiras letras, atrelando-o diretamente a uma perspectiva moral, como se o conhecimento daí derivado fosse um prolongamento dos costumes e comportamentos da vida adulta. Identificando a moral como a "ciência que dirige as ações do homem para o bem, ou a ciência dos nossos deveres" (Monteverde, 1865: 3), Monteverde inicia o referido compêndio, que, naqueles anos 60 , era já um dos principais livros didáticos da escola primária portuguesa; além de haver também indícios de sua presença no Brasil ${ }^{4}$.

Recordando que a etimologia da palavra moral remonta a idéia de costumes, Monteverde, em seu compêndio, definirá: "os costumes são inclinações que nascem conosco, e se desenvolvem por atos reiterados. Essas inclinações chamam-se bons ou maus costumes, segundo são conformes ou contrários às regras estabelecidas" (Monteverde, 1865: 3). Aqui a universalidade moral é relativizada pela circunscrição histórica e geográfica. Serão os usos e costumes de cada sociedade que definirão os códigos do 
bem agir; embora esses, contraditoriamente, não deixem de ser universalmente válidos. Seja como for, para os integrantes de cada específico grupo social, a moral seria imperativa porque regula parâmetros coletivos de convivência. Há mesmo assim o intuito claro de expor valores imanentes expressos em comportamentos passíveis de ser universalmente julgados.

A ética é aqui sistematizada como um campo teórico. A moral é compreendida como ciência do bem; e o livro escolar expressaria o repertório desse bem a ser traduzido em atos. Procede-se, como se vê, à naturalização das relações de poder na sociedade. Como artifício, não se confere maior valor de verdade a conteúdos matemáticos ou científicos do que a preceitos éticos ou normativos. Desse modo, a obediência aos pais é revestida, por exemplo, de valor universal: qualquer filho precisará obedecer em qualquer tempo qualquer ordem de seu pai. A criança, que é como o bárbaro, por definição, é também o servo. Sendo assim, nos termos do texto:

Entre os turcos, e mesmo entre os árabes, o chefe de uma família tem sido sempre uma personalidade sagrada para seus filhos. Entre aqueles povos, um filho jamais contraria seu pai; só aparece na sua presença quando lh'o determina, e com maior submissão, conservando-se sempre em pé até que ele o mande sentar (Monteverde, 1865: 10).

A escola deriva todo dever de subordinação dessa relação primária entre pais e filhos. Os homens, por serem obrigados a viver juntos, dividir-seiam de modo hierarquizado; o que leva a que alguns obedeçam e outros mandem, demarcando um território cindido entre inferiores e superiores. A criança, além disso, deverá ser preparada para encontrar e aceitar como naturais as explosões de pessoas coléricas. Diz Monteverde que são deveres gerais das pessoas acomodarem-se ao gênio daqueles com quem convivem. O texto, sobre isso, transforma em ética normativa os usos e costumes:

Devemos estar preparados a encontrar na sociedade pessoas desconfiadas, que se encolerizam sem causa, que tomam tudo às avessas, que discorrem mal, que mostram um orgulho arrogante, ou uma condescendência desprezível e desagradável. Uns são mui fogosos, outros demasiadamente frouxos. Estes contrariam sem razão, aqueles não podem sofrer que os contrariem. Uns são curiosos e malignos, outros insolentes sem terem a mínima atenção com pessoa alguma. Outros, persuadidos de que tudo lhes é devido, não obsequiam ninguém, não deixando, contudo, de dar a conhecer que exigem ser obsequiados. Estes e tantos outros defeitos são, sem dúvida, insuportáveis, mas é do nosso dever desculpá-los (Monteverde, 1865: 26). 
Desculpam-se assim os maus-tratos dos adultos sobre as crianças e os possíveis indícios de violência familiar; já que os adultos são, ligeiramente, apresentados como sujeitos de suas paixões; com comportamento compreensivelmente descomedido, em virtude de disposições de natureza. Às crianças, caberá aceitar com docilidade as expressões de desequilíbrio de seus pais.

As relações sociais ancorar-se-iam na civilidade, compreendida como visível "sinal distintivo da boa educação" (Monteverde, 1865: 240). Tomando como necessário o fato de os homens julgarem seus semelhantes em virtude das aparências, seria imprescindível ao homem educado, por intermédio das mesmas aparências, agradar aos outros. Nesse sentido, "se suas maneiras forem incivis, conclui-se que são a conseqüência do seu caráter e dos seus costumes. Pensa-se e com razão que todo aquele que procura emancipar-se das leis da civilidade, pretende dar largas a seus defeitos (Monteverde, 1865: 241).

O aprendizado da civilidade engloba a incorporação de modos: modos de se conduzir na rua e nos lugares públicos; modos de se apresentar nas igrejas; modos de estar perante pessoas de cerimônia. Nesse último caso, são sublinhadas recomendações relativas à postura do corpo. Há de se observar os movimentos dos outros; até para apreender os bons exemplos a serem imitados. A observação dos outros é, ainda, pedagógica para que se possa aprender a arte de conquistá-los: "a arte de manobrar os homens era a aplicação da arte de os observar e as duas disciplinas enriqueciam-se mutuamente" (Elias, 1987: 81). A materialidade corporal torna-se objeto de um olhar arguto e calcado sobre estratégias de longo prazo. Sendo assim, a postura do corpo deverá ser minuciosamente governada com a intenção de ver e de ser vista:

Que se deve observar quando se está de pé? - Não se curvar, nem inclinar a cabeça com indolência ou afetação, nem tampouco levantá-la demasiado, para não ser tido em conta de altivo. Cometerá uma incivilidade aquele que se encostar à parede, aos móveis, principalmente à cadeira de outrem, fizer trejeitos, etc. Qual é, pois, a melhor postura quando se está de pé diante das pessoas de respeito? - Ter a cabeça e o corpo direitos, os calcanhares pouco separados, os bicos dos pés para fora, os braços caídos, mas um deles algum tanto dobrado, tudo sem afetação. Que postura deve guardar quem está sentado? - A mais modesta e menos incômoda para os que andarem a seu lado. Não deve sentar-se atravessado, nem passar o braço pelas costas da 
cadeira. É incivil adormecer, bocejar, recostar-se, balancear-se, cruzar as pernas, descansar os pés nas travessas das cadeiras, esfregá-los no sobrado, levantar-se sem precisão quando todos estiverem sentados, ficar sentado quando os outros se levantarem, firmar o cotovelo no braço da cadeira, e descansar a cabeça na mão. (Monteverde, 1865: 246-7).

Se há algum sentimento de infância expresso no repertório do compêndio escolar, trata-se da tentativa sistemática de retirar a criança de seu universo para construir o sujeito-aluno: regrado, normalizado; sob medida. Afinal, o que é a escola? "A escola é a reunião de crianças que tomam o nome de alunos, e que recebem as lições dum mesmo mestre chamado professor" (Castanheira, 1903: 82). O aluno é, por seu turno, o futuro adulto. $\mathrm{O}$ aluno pertence a rigor a sua própria posteridade. A escola auxilia a família a ensinar a criança sobre o bem; e bem educá-la para a civilização. As condutas indicadas como impróprias seriam, pois, indícios sociais de hábitos existentes, distribuídos nas práticas de várias camadas da sociedade; e que deveriam ser substituídos por outras formas de agir. A cultura que a escola produz - pode-se então dizer - é tanto interna quanto exterior. A escola é formada e forma; reproduz e produz cultura; apropria-se deles e transforma saberes e valores, ao mesmo tempo em que engendra outros (Petitat, 1994: 18). Há sim transposição didática (Chevallard, 1991); e há também inventividade (Chervel, 1998: 14) ${ }^{5}$. O aparente paradoxo equaciona-se exatamente à luz da reinvenção, nos usos e costumes da escola, dos múltiplos significados culturais ali recebidos e entrecruzados.

O estudo da civilidade escolar, por meio do livro didático, é bastante indicativo dos sentidos da escolarização. A civilidade separa as pessoas; divide a sociedade em fatias; demarca claramente fronteiras de classes, a despeito de seu verniz aparentemente universalista 6 . A civilidade prescreve usos sociais de convivência, que vão desde o asseio até o aprendizado da 'arte da conversação'. As crianças, ao mesmo tempo em que devem acatar com docilidade o caráter temperamental dos adultos, precisarão aprender a se portar diante deles de maneira agradavelmente estóica. A forma de demonstrar respeito implicaria por isso a abstenção "de levantar a voz, gesticular, olhar fixamente para aqueles que lhes falarem, rir às gargalhadas, bocejar sem porem a mão ou o lenço diante da boca" (Monteverde, 1865: 265). Há aspectos bastante usuais; e que ainda nos são extremamente familiares como convenções da vida social. Para que a criança não 
desagrade, será necessário "saber calar-se, e saber ouvir. Há mais quem se tenha arrependido de ter falado do que de haver guardado silêncio" (Monteverde, 1865: 265).

A meninice é assim advertida: não se deve ser estouvado nem distraído; não se deve falar coisas ao ouvido nem exprimir-se em língua que os outros não compreendam. Não é polido gabar-se da própria saúde diante de pessoas doentes. Também não é de bom tom falar de idade na frente dos velhos ou da riqueza diante daqueles que têm poucas posses. Quando se fala, não se deve, todo tempo, perguntar às pessoas se elas compreenderam o que se disse. Enfim, não é apropriado, do ponto de vista da civilidade, "despertar a inveja ou o sentimento dos que são menos felizes do que nós" (Monteverde, 1865: 266). São também apresentados como práticas de civilidade o respeito e adesão perante a religiosidade e as leis do país. Os principais vícios indicados pelo Manual Encyclopedico seriam os seguintes: "presunção, egoísmo, suscetibilidade, espírito de contradição desconfiança, curiosidade" (Monteverde, 1865: 267-8). Não se deve fazer perguntas indiscretas; nem rir sem motivos ou dar gargalhadas. Não é polido dar mostras de erudição. E principalmente, não é bonito falar de si. De qualquer maneira, ao contestar alguém que foi grosseiro, também compete ter urbanidade - já que "as palavras comedidas abrandam a cólera; as palavras ásperas excitam o furor" (idem, p.270).

Em livro publicado em 1854, sob o título Encyclopedia das escolas d'instrucção primaria, Julio Caldas Aulete e José Maria Latino Coelho declaravam pretender substituir o acima referido Manual encyclopedico, que Monteverde originariamente publicara em 1838. Os autores evocavam também a idéia de civilização para justificar o lançamento da sua obra. $O$ caráter enciclopédico é aqui defendido como correlato ao estágio de uma sociedade dirigida por parâmetros de um progressivo e incessante aprimoramento. Não se trata de cristalizar comportamentos, saberes ou valores tidos por inamovíveis. Compreende-se, contudo, que a mesma sociedade que progride em relação a conquistas materiais teria perdas em relação a épocas passadas quanto aos frutos do espírito. A pressa do tempo deformaria antigos hábitos. Cumpria à educação fazer com que os mesmos fossem reerguidos. O século era visto como utilitário e egoísta. Mais do que isso: 
É o século mais utilitário que piedoso, mais entusiasta de empresas industriais que de generosos cometimentos. Há mais deferência recíproca e menos caridade; há mais egoísmo e menos afeto fraternal. Os interesses materiais e o espírito mercantil apagaram os caracteres generosos que distinguiam as gerações passadas. A máquina a vapor trabalhando em toda a parte simboliza a vitória do sistema utilitário sobre todos os princípios de abnegação e heroicidade. Não está em nossa mão derrubar os emblemas da indústria e restituir à sociedade a vida simples e frugal da idade de ouro. Não podemos erguer altares ao espírito, e esquecer de todo na educação e no ensino a tendência com que os homens de hoje marcham a alcançar o império das coisas mundanas e profanas. Como educadores da puerícia o nosso dever é corrigir os efeitos e as exagerações do nosso século, sem lhes tirar os caracteres que lhe imprimem a sua individualidade. Aliar numa união possível e racional o espírito e a matéria, sem que a moralidade se curve ao egoísmo, e sem que os direitos da inteligência se humilhem diante dos interesses físicos, é o pensamento deste livro que nós oferecemos ao público sob o título Encyclopedia das escolas primarias (Aulete \& Coelho, 1854: XI).

Caldas Aulete e Latino Coelho referiam-se a dois tipos de civilidade: 0 primeiro deles universal, fundado no "interesse recíproco" do gênero humano, e o outro convencional; variando, portanto, de acordo com o lugar e com a época. No primeiro caso, "a moral universal manda a todo homem, qualquer que seja a sua religião, que não cause dano aos outros homens, antes os auxilie e favoreça" (Aulete \& Coelho, 1854: 20). A civilidade convencional estaria, por sua vez, sujeita ao "capricho da boa sociedade", sendo a moda seu "juiz inexorável (idem, ib.)". Diria respeito a aspectos concernentes ao que as sociedades chamam de bom tom: "a amabilidade, a elegância fidalga das maneiras, o trato cortesão, os primores e as galanterias da urbanidade" (idem, pp.20-1). As duas civilidades exigiriam esforço de diferenciação, já que não podem e não devem ser apreendidas da mesma maneira:

Devemos distinguir cuidadosamente entre a civilidade que nos serve a cada instante e em cada situação da nossa vida, e aquela que, como complemento da primeira, torna o homem, além de bem educado e cortês, elegante e primoroso. Esta civilidade não se aprende decerto nos livros, nem pode entrar como elemento de instrução primária. Quem aspirar às honras de pontual em todas as mil etiquetas e formalidades que a moda e a civilização tem ido todos os dias inventando, há de ir aprendê-las nas salas e completar pela freqüência do que se chama o grande mundo a educação que neste ponto haja recebido na escola e na família (Aulete \& Coelho, 1854: 34).

O bom tom passava também pela arte da conversação, que, como adverte Peter Burke (1995: 120), indica formas registradas como códigos de 
tratamento cotidiano das camadas sociais econômica e politicamente privilegiadas. O compêndio, então, aludia a um gênero de literatura, que objetivava ensinar as pessoas a falar em diferentes ocasiões. A finalidade seria a de auxiliar o indivíduo a se mostrar (ou mesmo a parecer) bem nascido. Evidentemente a divulgação desse receituário nas escolas primárias indiciava algum esforço para familiarizar camadas mais amplas da população com os resultados distintivos da cultura das letras. Aqueles que não são bem nascidos, se letrados, comportar-se-ão como tal. É de bom tom aprender a se comportar como as elites; adquirir seus sinais distintivos. A escola ensinaria isso.

Não cabe aqui averiguar se "as conversações seguem regras ou princípios, e em que sentido tais regras ou princípios devem ser entendidos (de maneira estrita ou flexível, seguidos conscientemente ou observados de fora, e assim por diante)" (Burke, 1995: 121); já que, segundo Burke, há controvérsias entre os lingüistas acerca da questão. Porém havia, sim, na Encyclopedia das escolas d'instrucção primaria, claras recomendações quanto às formas de aprender uma prática que se deveria colar à pele, tornando rotineiro o trato polido entre as pessoas. A conversação é primeiramente exposta como um laço, que, enquanto tal, une os homens. Por possuir tal dimensão agregadora, a mesma conversação precisará ser criteriosamente estruturada; de modo que a interlocução entre as pessoas não se torne desagradável e permeada por equívocos. Sendo assim, para ser correta, a conversação deverá ser "singelamente fluida e eloqüente, graciosamente espirituosa e frisante sem degenerar nunca em maledicente ou em mordaz" (Aulete \& Coelho, 1854: 30). Essa arte de conversar seria o antídoto contra o risco que toda a pessoa em sociedade corre: o de ser um incômodo para os outros. Nesse sentido, continua o texto:

Narrar bem um acontecimento, discursar sobre um assunto dos que tem curso legal nos salões, contar um caso que vem a propósito, inventar ou reproduzir uma anedota frisante, citar sem pedantismo um trecho de erudição, um feito histórico, uma passagem de um poeta ou de um escritor notável, dizer chistes e gracejos agradáveis e inocentes, conseguir que muitas pessoas reunidas numa sala estejam, enquanto nós falamos, como que pendentes dos nossos lábios, incutir-lhes o entusiasmo, acender-lhes a imaginação, comovê-las pela onipotência da palavra, ou promover-lhes facilmente o riso por ditos conceituosos e engraçados, - só pode ser fruto de um engenho fácil, aprimorado pela arte e enriquecido pela educação literária e científica (Aulete \& Coelho, 1854: 31). 
Percebe-se - seja pela palavra do professor, seja pelo conteúdo dos compêndios - alguma coisa que, na vida escolar, situa-se para além da relação com o conhecimento. A escola se expressa socialmente como instituição estratégica para, por seus ritos (Boto, 1997), firmar comportamentos. Práticas de civilidade aliam-se ao aprendizado da ética. Conhecer o bem supõe o bem agir. As narrativas de que se vale a escola, bem como os conteúdos culturais de seus saberes, têm cumplicidade com o firmamento de roteiros de condutas válidas. Compreender a cultura escolar, em seu interior, supõe conhecer como as coisas são designadas na sala de aula. Os livros didáticos, nesse sentido, indicam práticas e demonstram o lugar ocupado pela escolarização no processo civilizador (Elias, 1993). Poderíamos nos indagar: é possível educar em escolas de outro modo? É desejável? Como ensinar sem ensinar comportamentos? Anne-Marie Chartier sublinha como um fato essa dimensão normativa da vida escolar:

A escola escolhe, deve escolher, entre todos os saberes possíveis, aqueles que têm valor de formação para as gerações jovens. Ou ainda aqueles que 'a sociedade' acredita que não sejam apenas úteis, mas necessários, importantes, educativos. A cultura a transmitir, tal qual ela é definida tradicionalmente, é, portanto, o que faz o objeto de uma crença partilhada, crença não individual, mas coletiva e inscrita nas instituições (Chartier, 2005: 26).

Todavia há, dentre os mesmos saberes escolares, alguns aspectos generosos e outros cruéis (Nóvoa, 1991, 1995). É preciso conhecer essa história para de fato ponderarmos sobre o lugar cultural que a escola ocupa nas sociedades, enquanto instância privilegiada de formação e socialização das gerações jovens. Trata-se, inequivocamente, de uma herança que nos foi legada. A partir daí, competirá também à pedagogia meditar sobre o seguinte: merece o modelo da escola moderna ser preservado para aqueles que vierem depois de nós?

Em alguma medida, educar também é prevenir a barbárie; embora muito do que oferece nossa tradição educativa possa ser compreendido como bárbaro; até porque, como observa Francis Wolff, "existem, sim, bárbaros e civilizados, práticas ou culturas bárbaras, práticas ou culturas civilizadas, mesmo que toda cultura, qualquer que seja, possa ser exemplo de civilização ou mergulhar na barbárie" (Wolff, 2004: 43).

A barbárie contemporânea pode ser qualificada como a outra face do percurso civilizador; daí o risco. Ela estará ligada a um rescaldo de "uma 
agressividade primitiva, um ódio primitivo ou, na terminologia culta, um impulso de destruição, que contribui para aumentar ainda mais o perigo que toda esta civilização venha a explodir" (Adorno, 1995: 155). A tendência para a barbárie seria, como diz Adorno, imanente à civilização. Como as crianças enquanto crianças não podem ditar suas próprias leis, é preciso que o mundo dos adultos as auxilie. Meditar sobre os impasses da escolarização de nosso tempo requer o escrupuloso exercício de se averiguar quais os modos pelos quais o ritual escolar tem trabalhado com os temas ligados aos valores e ao comportamento. O que se diz da ética? Como se pensa o tema da justiça? Quais os critérios de recompensas e punições em vigor? Como a escolarização lida com exemplos? Buscar compreender a escola sob o traço do percurso civilizador das sociedades do Ocidente é motivo suficiente para inquirir o ritual escolar. Dialogar sobre o assunto, assumindo-o como tema da educação, poderá, por fim, contribuir para engendrar uma sociedade de hábitos educativos mais inventivos, mas também mais delicados; e, sobretudo, mais solidários. A história da escola terá a continuidade que nós criarmos para ela.

\section{Notas}

1 Em alguns casos, a justificativa do dever é a figura de Deus, como no capítulo intitulado "A mentira" do Livro dos meninos christãos ou instrucções religiosas de uma mãe a seus filhos, obra cuja tradução (em segunda edição, datada de 1867) era utilizada em escolas portuguesas de meados do século XIX. Ali o texto claramente dirá que "Deus abomina a mentira, meus caros filhos, por ser obra do demônio, seu inimigo, o primeiro que a introduziu no mundo para enganar nossos primeiros pais. Por essa razão, a Sagrada Escritura chama pai da mentira ao espírito maligno; e Deus, que ama com particularidade a virtude contrária a este vício, chamou a si mesmo o Deus da verdade. Que mais é preciso, meus amigos, para ter horror à mentira?" (LIVRO dos meninos christãos, 1867: 179).

2 Para Kant, o conceito de moralidade vem ancorado à perspectiva da vontade autônoma: "a vontade é concebida como a faculdade de se determinar a si mesmo e agir em conformidade com a representação de certas leis. E uma tal faculdade só se pode encontrar em seres racionais" (Kant, 1988: 67).

3 "A escola é Sol bendito/ Que a nossa alma alumia/ Converte a Treva em luz/ Converte a Noite em Dia/ É astro rutilante/ De esplêndido clarão/ A luz, que ela irradia/ Chama-se Instrução/ Luz doce e peregrina / Que alegra e que consola / Bem haja o Professor / Bendita seja a Escola / Felizes os que têm / Quem os ensine a ler / Quem Ihes aponte a franca / Estrada do dever / Quem Ihes dissipe a Treva / 
Que a mente lhes inunda / Da ignorância a noite / É tão triste e profunda / Bem haja o Professor / Que dá a Educação / Bendita seja a Escola / Bem haja a Instrução" (Prof. Manuel Subtil, apud, Machado, s/d, p. 8).

4 Circe Bittencourt, em sua tese de doutorado, referindo-se a diagnóstico crítico efetuado por José Veríssimo em 1890 acerca da recente tendência nacionalista dos escritores de obras didáticas, transcreve o seguinte trecho do referido autor: "São os escritores estrangeiros que, traduzidos, trasladados ou quando muito servilmente imitados, fazem a educação de nossa mocidade. Seja-me permitida uma recordação pessoal. Os meus estudos feitos de 1867 a 1876 foram sempre em livros estrangeiros. Eram portugueses e absolutamente alheios ao Brasil os primeiros livros que li. O Manual Enciclopédico (...) as seletas portuguesas de Aulete, os ornamentos da memória, de Roquette - foram os livros em que recebi a primeira instrução. (...) Neste levantamento geral, que é preciso promover a favor da educação nacional, uma das mais necessárias reformas é a do livro de leitura. Cumpre que ele seja brasileiro, não só feito por brasileiro, que não é o mais importante, mas brasileiro pelos assuntos, pelo espírito, pelos autores trasladados, pelos poetas reproduzidos e pelo sentimento nacional que o anime" (J. Veríssimo, apud Bittencourt, 1993: 20).

5 Diz André Chervel, sobre o tema, que "contrariamente ao que possamos acreditar, a teoria gramatical ensinada na escola não é expressão das ciências ditas ou presumidas de referência, mas ela é historicamente criada pela própria escola, dentro da escola e para a escola" (Chervel, 1998: 14).

6 O recurso à civilidade também era utilizado como tática na educação familiar, quando pais procuram incutir nos filhos os comportamentos desejados pela 'boa sociedade' adulta. Trata-se claramente de um cenário social fraturado em camadas que se sobrepõem umas às outras, mas permanecem claramente diferenciadas. Há os superiores, os inferiores (criados) e os iguais; como demonstra o excerto seguinte, extraído de um compêndio de civilidade, produzido pela redação da revista Educação Nacional na primeira década do século XX português: "nunca deve deitar-se sem que se despeça de seus superiores, cumprimente os seus iguais, deseje uma boa noite aos seus inferiores. Se qualquer deles reclamar um seu serviço, não deve deixar de os atender prazenteiramente, adiando a hora de se deitar, quando for preciso. Nesta conjuntura, se o sono o entorpecer, usará de todos os meios, até do exercício físico, para se vencer e ter a felicidade de ser útil aos seus semelhantes com algum sacrifício (...) Despedindo-se dos inferiores, seja despretensioso, respeitador, amável, sem precisar de mostrar-se zombeteiro e leviano com o pretexto de parecer afável. Evite, porém, os ridículos ares de grande senhor com que muitos meninos julgam tornar-se imponentes, não conseguindo, porém, mais do que tornar-se antipáticos" (A CIVILIDADE, 1907: 22-3).

\section{Referências}

ADORNO, Theodor W. (1995). Educação e Emancipação. São Paulo: Paz e Terra.

ALAIN, Quadrige (1986). Propos sur L'éducation suivis de Pedagogie Enfantine. Paris: Presses Universitaires de France. 
ANAQUIM, Cônego Manuel (1906). Compêndio de Moral e Doutrina Christã. Lisboa: Livraria Ferreira.

ARENDT, Hannah (2000). Entre o Passado e o Futuro. 5ª ed. São Paulo: Perspectiva.

ARISTÓTELES (1987). Ética a Nicômaco. In Os Pensadores. Volume II. São Paulo: Nova Cultural.

AULETE, Julio Caldas \& COELHO, José Maria Latino (1854). Encyclopedia das Escolas D'instrucção Primaria. Lisboa: Typographia Universal.

BARREIROS, Carlos Joze (1858). Elementos de Moral para Uso das Escolas. Terceira Edição adequada à capacidade dos alunos d'instrucção primaria. Poço do Borratem nํㅜ: Typographia de Leal \& Ca․

BASTOS, M. H. C (2002). Pro Patria Laboremus: Joaquim José de Menezes Vieira (1848-1897). Bragança Paulista/SP: Editora da Universidade de São Francisco. v. $1.350 \mathrm{p}$.

BEAUVOIR, Simone de (1970). Moral da Ambigüidade. Rio de Janeiro: Paz e Terra.

BITTENCOURT, Circe Maria Fernandes (1993). Livro Didático e Conhecimento Histórico: uma História do Saber Escolar. Tese de Doutorado da Faculdade de Educação da Universidade de São Paulo [mimeo].

вОтO, Carlota Josefina Malta Cardozo dos Reis (1997). Ler, Escrever, Contar e se Comportar: a Escola Primária como Rito do século XIX Português (1820-1910). Tese de Doutorado da Faculdade de Filosofia, Letras e Ciências Humanas da Universidade de São Paulo [mimeo].

BURKE, Peter (1995). A Arte da Conversação. Trad: Álvaro Luiz Hattnher. São Paulo: Unesp.

BURKE, Peter (2005). O que é História Cultural? Trad: Sérgio Goes de Paula. Rio de Janeiro: Zahar.

CAMBI, Franco (1999). História da Pedagogia. São Paulo: Unesp.

CAMPS, Victoria (1996). Virtudes Públicas. 3ㄹed. Madrid: Editorial Espasa Calpe.

CARVALHO, José Sérgio Fonseca (s/d). A crise na educação como crise da modernidade. Revista Educação, Especial: Hannah Arendt Pensa a Educação. Biblioteca do Professor. São Paulo: Segmento, pp. 16-25.

CARVALHO, Marta Maria Chagas de (2001). A caixa de utensílios e a biblioteca: pedagogia e práticas de leitura. In D. G. Vidal; M. L. S. Hilsdorf.Tópicas em História da Educação. São Paulo: Edusp, pp. 137-167.

CARVALHO, Marta Maria Chagas de (2006). Livros e revistas para professores: configuração material do impresso e circulação internacional de modelos pedagógicos. In J. Pintassilgo; M. M. C. Carvalho; M. C. Freitas; M. J. Mogarro (Orgs.), História da Escola em Portugal e no Brasil. Circulação e Apropriação de Modelos Culturais. Lisboa: Colibri/Centro de Investigação em Educação da Faculdade de Ciências da Universidade de Lisboa, pp. 141-173.

CASTANHEIRA, Padre José Correia Marques de (1903). Doutrina Christã e Moral para Uso dos Alumnos das Escolas Primarias: em harmonia com os programmas officiaes. Coimbra: Imprensa da Universidade.

COMPÈRE, Marie-Madaleine, Org. (1997). Histoire du Temps Scolaire en Europe. Paris: Institut National de Recherche Pédagogique. 
CATANI, Denise B.; BUENO, Belmira; SOUSA, Cynthia Pereira de (2000). O amor dos começos: por uma história das relações com a escola. Cadernos de Pesquisa da Fundação Carlos Chagas. São Paulo, n.111, pp. 151-171.

CATANI, Denise B.; SOUSA, Cynthia Pereira de; NÓVOA, António; SIMON, Frank (2005). School and modernity: knowledge, institutions and practices introduction. Paedagogia Histórica. Bélgica. v.XLI, n.I \& II, pp.1-8.

CHARTIER, Anne-Marie (2005). Escola, cultura e saberes. In L. N. Xavier; M. M. C. Carvalho; A. W. Mendonça; J. L. Cunha (Orgs.), Escola, Cultura e Saberes. Rio de Janeiro: Editora FGV, pp. 9-28.

CHAUÍ, Marilena (1980). Ideologia e educação. Educação e Sociedade, CEDES/Cortez Editora/Autores Associados, ano II, n5, pp. 24-40.

CHERVEL, André (1998). La Culture Scolaire. Paris: Belin.

CHEVALLARD, Yves (1991). La Transposition Didactique: du Savoir Savant au Savoir Enseigné. Paris: La Pensée Sauvage.

A CIVILIDADE pela redacção da Educação Nacional (1907). Porto: Livraria Figueirinhas.

COHN, Gabriel (2004). Indiferença, nova forma de barbárie. In A. Novaes (Org.), Civilização e Barbárie. São Paulo: Companhia das Letras, pp. 81-9.

CRITELLI, Dulce (s/d). O ofício de pensar. Revista Educação, Especial: Biblioteca do Professor. São Paulo: Segmento, pp. 74-83.

CUNHA, Maria Teresa Santos (2007). Ser de cerimônia: manuais de civilidade e a construção de sujeitos históricos. In M. A. Nepomuceno; E. F. A. Tiballi (Orgs.), A Educação e seus Sujeitos na História. Belo Horizonte: Argumentum Editora, pp. 91-108.

ELIAS, Norbert (1987). A Sociedade de Corte. Trad: Ana Maria Alves. Lisboa: Editorial Estampa.

ELIAS, Norbert (1975). La Dynamique de l'Occident. Paris: Calmann-Lvy.

ELIAS, Norbert (1994). O Processo Civilizador: uma História dos Costumes. Volume I. Trad: Ruy Jungmann. Rio de Janeiro: Zahar.

ESCOLANO, Agustín (1998). Arquitetura como programa: espaço-escola e currículo. In A. Viñao Frago; A. Escolano, Currículo, Espaço e Subjetividade: a Arquitetura como Programa. Rio de Janeiro: DP\&A.

FARIA FILHO, Luciano Mendes (2005). Cultura escolar e cultura urbana: perspectivas de pesquisa em história da educação. In L. N. Xavier; M. M. C. Carvalho; A. W. Mendonça; J. L. Cunha (Orgs.), Escola, Cultura e Saberes. Rio de Janeiro: Editora FGV, pp. 29-37.

FARIA FILHO, Luciano Mendes \& VAGO, Tarcísio Mauro (2001). Entre relógios e tradições: elementos para uma história do processo de escolarização em Minas Gerais In D. G. Vidal; M. L. S. Hilsdorf. Tópicas em História da Educação. São Paulo: Edusp, pp. 117-136.

FISCHMANN, Roseli (2006). Pluralidade cultural e formação de professores: entre o passado e o futuro. Revista de Educação CEAP. V.55, pp. 12-16. 
FORQUIN, Jean-Claude (1993). Escola e Cultura: as Bases Sociais e Epistemológicas do Conhecimento Escolar. Porto Alegre: Artes Médicas.

FOUCAULT, Michel (1987). Vigiar e Punir. 27ª̣ed. São Paulo, Editora Vozes.

FRANCISCO, Maria de Fátima Simões (s/d). Preservar e renovar o mundo. Revista Educação. Especial: Hannah Arendt Pensa a Educação. Biblioteca do Professor. São Paulo: Segmento. pp. 26-35.

FREUD, Sigmund (1997). O Mal-estar na Civilização. Rio de Janeiro: Imago.

GUSDORF, Georges (1970). Professores para quê? Lisboa: Moraes.

HILSDORF, Maria Lucia Spedo (1998). Pensando a Educação nos Tempos Modernos. São Paulo: Editora da Universidade de São Paulo.

JULIA, Dominique (2001). A cultura escolar como objeto histórico. Revista Brasileira de História da Educação. SBHE-Sociedade Brasileira de História da Educação. no1. Campinas: Editora Autores Associados, pp. 9-43.

KANT, Immanuel (1988). Fundamentação da Metafísica dos Costumes. Lisboa: Edições 70.

LIVRO dos meninos christãos ou instrucções religiosas de uma mãe a seus filhos (1867). Traduzido do francez. $2^{\mathrm{a}}$ ed. Lisboa: Typographia G. M. Martins.

LOPES, José Quintino Travassos (1897). Leituras Correntes e Intuitivas: obra approvada por decreto de 23 de outubro de 1897 para a $2^{a}$ classe das escolas de instrucção primaria. Lisboa: Typographia e Stereotypia Moderna.

MACHADO, Ulysses (s/d,a). Livro de Leitura para a Segunda Classe do Ensino Primário Geral. $15^{\mathrm{a}}$ ed. Lisboa: Centro Tipografico Colonial.

MACHADO, Ulysses (s/d,b). Livro de Leitura para a Terceira Classe do Ensino Primário

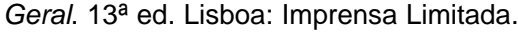

MARTINS, Guilherme d'Oliveira (1998). Educação ou Barbárie?: Ensaios. Lisboa: Gradiva.

MIDOSI, Henrique C. (1846). Poesias selectas para leitura, recitação e analyse dos poetas portuguezes em conformidade com programmas adoptados para 0 curso de portuguez e litteratura. Quarta edição; ornada de estampas, e muito aumentada. Lisboa: Imprensa Nacional.

MINISTÉRIO DO REINO (Mç. 3527). (1851). Arquivo Central das Secretarias de Estado.

MONTEVERDE, Emílio Achilles (1865). Manual Encyclopedico para Uso das Escolas D'instrucção Primaria. Oitava edição, revista e melhorada. Lisboa: Imprensa Nacional.

MORAL e educação cívica do ensino primário elementar: em harmonia com o Decreto nำ16730, publicado no Diário do Governo nํ3, 1a série de 13-4-1929. (1930). Porto: Casa Editora Figueirinhas.

NEMO, Philippe (2005). O que é o Ocidente? Trad: Guilherme João de Freitas Teixeira. São Paulo: Martins Fontes.

NÓVOA, António (1991). Para o estudo sócio-histórico da gênese e desenvolvimento da profissão docente. Teoria e Educação, 4. 
NÓVOA, António, Org. (1995). Profissão Professor. Porto: Porto Editora.

NÓVOA, António (2002). Ways of thinking about education in Europe. In A. Nóvoa; M. Lawn, Fabricating Europe: the Formation of an Education Espace. Dordrecht/Boston/London: Kluwe Academic Publishers, pp. 131-155.

PETITAT, André (1994). Produção de Escola/Produção de Sociedade. Porto Alegre: Artes Médicas.

PINTASSILGO, Joaquim; CARVALHO, Marta M. C.; FREITAS, Marcos C.; MOGARRO, Maria J., Orgs. (2006). História da Escola em Portugal e no Brasil. Circulação e Apropriação de Modelos Culturais. Lisboa: Colibri/Centro de Investigação em Educação da Faculdade de Ciências da Universidade de Lisboa.

PIRES, M. J. (1851). Rudimentos da Leitura Portugueza com Exercicios para Soletrar em Lettra Redonda, Italica, Gothica e Manuscripta Offerecidos á Mocidade Elvense. Lisboa: Imprensa Nacional.

POSTMAN, Neil (1999). O Desaparecimento da Infância. Rio de Janeiro: Graphia.

REVEL, Jacques (1991). Os usos da civilidade. In P. Ariès; G. Duby, História da Vida Privada: da Renascença ao Século das Luzes. Trad: Hildegard Feist. São Paulo: Companhia das Letras, pp. 169-209.

RIBEIRO, Renato Janine (1990). A Etiqueta no Antigo Regime. 3ªed. São Paulo: Brasiliense.

SENNETT, Richard (1988). O Declínio do Homem Público: as Tiranias da Intimidade. São Paulo: Companhia das Letras.

SOUZA, Maria Cecília Cortez Christiano de (2000). A Escola e a Memória. Bragança Paulista: Editora da Universidade São Francisco (EDUSF).

SOUZA, Rosa Fátima (1998). Templos de Civilização: a Implantação da Escola Primária Graduada no Estado de São Paulo (1890-1910). São Paulo: Unesp.

STAROBINSKI, Jean (2001). As Máscaras da Civilização: Ensaios. Trad: Maria Lúcia Machado. São Paulo: Companhia das Letras.

STEPHANOU, Maria (2006). Bem viver em regras: urbanidade e civilidade em manuais de saúde. Educação Unisinos, v. 4, pp. 35-44.

TYACK, David \& CUBAN, Larry (1995). Tinkering Toward Utopia: a Century of School Reform. London: Harvard University Press.

VEIGA, Cynthia Greive (2005). Pensando com Elias as relações entre Sociologia e História da Educação. In L. M. Faria Filho (Org.), Pensadores Sociais e História da Educação. Belo Horizonte: Autêntica, pp. 139-166.

VIDAL, Diana (2000). Escola Nova e processo educativo. In E. Lopes; L. Faria Filho; C. Veiga, 500 Anos de Educação no Brasil. Belo Horizonte: Autêntica, pp. 497-518.

VIÑAO FRAGO, Antonio (1998). Tiempos Escolares, Tiempos Sociales: la Distribución del Tiempo e del Trabajo en la Enseñanza Primaria en España (1838-1936). Barcelona: Ariel.

VINCENT, Guy (direction) (1994). L'éducation Prisionnière de la Forme Scolaire: Scolarisation et Socialisation dans les Sociétés Industrielles. Lyon: Presses Universitaires de Lyon.

WOLFF, Francis (2004). Quem é bárbaro? In A. Novaes (Org.), Civilização e Barbárie. São Paulo: Companhia das Letras, pp. 19-43. 


\title{
THE SCHOOL RATIONALITY AS A CIVILIZING PROCESS: THE SOUL-CAPTURING
} MORAL

\begin{abstract}
The purpose of this article is to focus on the subject of civilization and practices of the teaching of morals and civility at school. By using the work of Norbert Elias as the main theoretical reference, Portuguese didactic books used in schools from the middle of the XIX century to the first years of the XX century were studied. This work, from the methodological point of view, expresses a research in the field of the History of Education, where the school texts are used as sources. By means of the books, the school purpose, which is to teach a set of behaviors deemed to be universally valid, is verified. In their turn, the text-books present different concepts of morality and several ways of conceiving the teaching of morals. The existence of clear strategies to couple the teaching of behavior ways to the teaching of reading, writing and reporting is noticed. The knowledge of junior high school clearly constitutes a way of civilizing. The concept of civilization implicitly brings the supposition of superiority of a culture over the others. The school knowledge unites with the teaching of certain abilities, of a given repertoire, that coincides with the course of values and knowledge to be sought, so that ideas of homeland, family, child, discipline, etc. are also formed. The school speaks of the world to the children; of a world to which some subtle teachings are necessary: the learning of silence, of modesty, of acceptance of the existent as being necessary, of the obedience as a value in the daily life.
\end{abstract}

Keywords

History of Education; Civilization; School; Text-books 


\section{LA RACIONALIDAD ESCOLAR COMO PROCESO CIVILIZADOR: LA MORAL QUE CAPTURA ALMAS}

\section{Resumen}

El objetivo de este artículo es el de enfocar el tema de la civilización y de las prácticas de enseñanza de la moral y de la civilidad en la escuela. Tomando por referencia teórica principal la obra de Norbert Elias, fueron estudiados libros didácticos portugueses utilizados en escuelas entre mediados del siglo XIX y los primeros años del siglo XX. Se trata de una investigación en el campo de la Historia de la Educación, en la cual los textos escolares son tomados como fuentes. Se verifica, por medio de los libros, la intención de la escuela de enseñar un guión de comportamientos estimados como universalmente válidos. Hay, por su parte, en los compendios, diferentes concepciones de moralidad y diversas maneras de concebirse la enseñanza de la moral. Se nota la existencia de estrategias claras para acoplar, a la enseñanza del leer, del escribir y del contar, la enseñanza de las formas de comportarse. Los saberes de la escuela primaria constituyen claramente una forma de civilizar. El concepto de civilización trae implícita la suposición de superioridad de una cultura sobre las otras. Los conocimientos escolares se alían a la enseñanza de ciertas competencias, de un determinado repertorio, que coincide con la orientación de valores y de saberes a ser recorridos; para que fueran formadas, inclusive, ideas de patria, de familia, de niño, de disciplina, etc. La escuela habla del mundo a los niños; de un mundo para el cual son necesarias algunas sutiles enseñanzas: el aprendizaje del silencio, de la modestia, de la aceptación del existente como necesario, de la obediencia como valor en la vida cotidiana.

Palabras clave

Historia de la Educación; Civilización; Escuela; Compendios didácticos

Recebido em Julho/2009

Aceite para publicação em Agosto/2010

\footnotetext{
Toda a correspondência relativa a este artigo deve ser enviada para: Carlota Boto, Alameda Franca, 260 apartamento 102, Jardim Paulista, CEP: 01422-000, São Paulo, Brasil. Telef.: 38150194; e-mail: reisboto@usp.br
} 